\title{
A representação audiovisual das mulheres migradas*
}

Luciana Pontes**

\section{Resumo}

Neste artigo analiso as representações sobre as mulheres migradas nos fundos audiovisuais de algumas entidades que trabalham com gênero e imigração em Barcelona. Por haver detectado nos audiovisuais analisados uma associação recorrente das mulheres migradas à pobreza, à criminalidade, à ignorância, à maternidade obrigatória e numerosa, à prostituição etc., busquei entender como tais representações tomam forma, estudando os elementos narrativos, estilísticos, visuais e verbais através dos quais se articulam essas imagens e discursos sobre as mulheres migradas.

Palavras-chave: Gênero, Migrações Internacionais, Audiovisuais.

" Recebido para publicação em 29 de outubro de 2009, aceito em 09 de fevereiro de 2011.

** Doutoranda em Mídia, Comunicação e Cultura pela Universidade Autônoma de Barcelona, Espanha. pontes.luciana@gmail.com

cadernos pagu (39), julho-dezembro de 2012:273-311. 
A representação audiovisual das mulheres migradas

The Audiovisual Representation of Migrant Women

\begin{abstract}
In this paper I analyze the representations of the migrant women at the audiovisual founds in some of the organizations that work with gender and immigration in Barcelona. At the audiovisuals I have found a recurring association of the migrant women with poverty, criminality, ignorance, passivity, undocumentation, gender violence, compulsory and numerous motherhood, prostitution, etc. Thus, I tried to understand the ways in which these representations are shaped, studying the narrative, stylistic, visual and verbal elements through which these images and discourses of the migrant women are articulated.
\end{abstract}

Key Words: Gender, International Migrations, Audiovisuals. 


\section{Introdução}

Atualmente, já existe um bom número de autoras/es que estudam a representação da migração nos meios de comunicação, sugerindo a importância das construções discursivas sobre o "imigrante"1, enquanto um "outro" "cultural" (Stolke, 1995), e a recorrência da associação entre "imigração", pobreza e marginalidade no contexto europeu contemporâneo (King, 2001; Lorite, 2004; Lario, 2006). Não obstante, também começam a surgir vozes que sugerem que, adicionalmente, tais representações constroem "o imigrante" como masculino. Como essas indicam, apesar da grande importância da migração feminina, existem poucos estudos sobre a representação audiovisual das mulheres migradas (Pérez, 2008; Argote, 2007).

Assim, partindo de uma grande área de interesse que compreende as representações das mulheres migradas na produção audiovisual em geral, nesta pesquisa analisei essas representações num terreno concreto: os fundos audiovisuais de algumas entidades ${ }^{2}$ que trabalham com gênero e migração na área metropolitana de Barcelona. ${ }^{3}$ Ao selecionar esse repertório

\footnotetext{
1 Assim como Sipi y Araia (2005), prefiro a palavra migrada/o a "imigrante", posto que esta tem conotações de transitoriedade e desarraigo (veja-se a crítica realizada, entre outros, por Rodrigo, 2006). Sem embargo, enquanto Sipi y Araia (2005) falam em imigradas, considero mais adequado o termo migrada/o, dado que o prefixo "in" fala sob a perspectiva do país receptor. Quando a palavra "imigrante(s)" aparece entre aspas, é para destacar que é esta a palavra utilizada pelo discurso comentado (dos meios de comunicação, por exemplo) e, portanto, relativizá-la.

2 As entidades são meramente fornecedoras de audiovisuais, não é do âmbito deste estudo analisar seu trabalho, nem tampouco a relação entre os discursos dos audiovisuais e o das entidades.

3 Essencialmente daquelas que cumpriam os requisitos de possuir fundos audiovisuais que contemplassem a interseção entre gênero e imigração, nomeadamente: o Institut Català de la Dona, o Centre de Cultura de Dones Francesca Bonnemaison, Drac Màgic, Ca la Dona, Museu d'història de la immigració de Catalunya e CIRD.
} 
A representação audiovisual das mulheres migradas

empírico, a investigação se enfocou nos pressupostos subjacentes à representação das mulheres migradas nesses produtos audiovisuais específicos, com o propósito de chegar a identificar relações entre os seus elementos visuais e narrativos com 0 contexto social da migração feminina em Espanha.

Esse trabalho, ainda que por opção metodológica estude gênero respeito à representação audiovisual das mulheres migradas, é consciente da crítica, extensamente desenvolvida nas teorias de gênero, da equiparação entre gênero e mulheres. Assim, ainda que se investiguem as representações de gênero relativamente às mulheres migradas, não se pretende reproduzir aqui de nenhum modo tal confusão. Num sentido similar, também se busca manter a cautela quanto à concepção da identidade feminina como uma e única (Butler, 1990), assim como relativamente aos perigos da reificação do uso da categoria "mulheres imigrantes" (Sipi e Araia, 2005). Portanto, ao falar de gênero entre as mulheres migradas, procuro: 1) não reduzir gênero a mulheres; 2) não desconsiderar a) toda a diversidade identitária de classe, etnia, opção sexual etc., existente entre as mulheres - $e$ que, obviamente, também existe entre as mulheres migradas - $e$ b) a interação de gênero com outros marcadores sociais; 3) não segregar e tipificar um grupo como "mulheres migradas", com tudo o que isso comporta de desconsideração da diversidade entre essas pessoas, como também de criação de estereótipos $e$ processos de exotização que não têm em conta as possíveis similaridades entre migradas e autóctonas/os. ${ }^{4}$

4 Não pertence ao âmbito deste trabalho uma discussão completa sobre a alteridade. Sem entrar em mais detalhes, considera-se aqui a/o "outra/o" o que em outras partes já se denominou mulheres "não-brancas", "não-ocidentais" etc. Em linhas gerais, seria aquela grande maioria da população mundial que, no sistema hierárquico do poder econômico, político, racial etc., está no lado subordinado dessas relações. Sem embargo, uma vez que o conceito de alteridade foi forjado em meio de relações de poder, esta definição não deixa de ser problemática, porque supõe um "nós" homem, branco, heterossexual, ocidental, etc. Também se há de observar que dentro desse "nós" branco, masculino, ocidental, etc., existem vários níveis de alteridade. 
Segundo o Fundo de População das Nações Unidas (2006), as 95.000 .000 mulheres migradas hoje no mundo representam $50 \%$ do total da migração internacional. Essa importância numérica da migração feminina se encontra relacionada às transformações do mercado laboral mundial e à necessidade do capital internacional de mão de obra barata. Algumas das mudanças mais significativas desse processo estão relacionadas com a crise do modelo tradicional de trabalho assalariado $e$ a formação de uma estrutura social fortemente dual, em que a flexibilização provoca um aumento da informalidade do mercado laboral e a exploração de massas de trabalhadores como força de trabalho excedente (Haraway, 1991).

Esse é um processo que implica praticamente toda a classe trabalhadora de todo o mundo, não obstante, tal processo afete especialmente as mulheres, sobretudo aquelas de grupos étnicos "minoritários" e dos países "pobres". O aumento dos mercados informais de trabalho é um dos principais motores da migração feminina, em uma contínua e intensa divisão "racial" e sexual do trabalho. Como sugere Haraway (1991) sobre as mulheres negras nos Estados Unidos, ou em Gregorio (2002) relativamente às dominicanas migradas em Madrid, essas mulheres empobrecidas e racializadas têm que manejar tanto a crescente exigência de manutenção da economia doméstica no país de origem ${ }^{5}$, como sua posição vulnerável na economia do trabalho assalariado.

Nas dinâmicas desencadeadas pelas migrações internacionais, gênero, classe $e$ nacionalidade/etnicidade conformam um processo social de desvalorização e exploração das mulheres migradas. Parella (2003) descreve este fenômeno entre as migradas na Espanha, demonstrando como essa mão de obra se incorpora em um mercado laboral já de por si bastante

\footnotetext{
5 Podem ser vários os fatores que constituem essa exigência, entre outros, a monoparentalidade, o subemprego estrutural dos homens, a obrigação de cuidado de idosos, menores, doentes e outros membros "incapacitados" da família, etc.
} 
A representação audiovisual das mulheres migradas

irregular, com uma grande importância do setor dos serviços e uma forte incidência de trabalho informal. Nesse contexto, as mulheres "do Sul" são recrutadas principalmente para o trabalho doméstico, para o cuidado de crianças e idosos, limpeza e hotelaria, sendo uma opção extremamente vantajosa por: 1) reduzir gastos para os empregadores, já que os salários são baixos e normalmente não se formaliza a relação laboral (evitando-se assim todos os gastos decorrentes dos direitos laborais $e$ prestações sociais); 2) paliar as carências geradas pela crise do Estado de Bem-Estar e as consequentes limitações nos serviços públicos, especialmente na oferta de vagas em creches $e$ geriátricos; 3) por ocupar os postos de trabalho abandonados pelas mulheres autóctonas, especialmente para executar o trabalho reprodutivo, num sistema em que os homens seguem evadindo de sua responsabilidade no trabalho doméstico.

Neste sentido, a migração feminina realizada nas presentes condições de subordinação de gênero e origem (categoria em que se combinam temas linguísticos, raciais, religiosos, etc.) são cruciais na construção da mulher migrada como mão de obra privilegiada no cuidado dos outros e da casa. Uma vez que seu trabalho se considera tipicamente feminino, essa naturalização supõe uma desvalorização extra do trabalho das mulheres migradas, já que "...se considera que para su realización no se requiere ninguna cualificación, sino habilidades que poseen las mujeres por el hecho de que toda mujer es potencialmente una madre y una esposa...." (Gregorio, 2002:26).

No entanto, gênero não atua isoladamente. A construção de representações sobre as mulheres migradas - e do seu lugar na sociedade receptora - é um processo polifacético, no qual interagem vários outros símbolos de status e distinção social:

...La naturalización de las tareas requeridas para el desempeño de estas actividades se "encarna" no sólo en el hecho de ser mujer, sino también en una suerte de clasificaciones o diferenciaciones que conllevan una serie de 
valoraciones jerarquizantes y discriminatorias. Diferenciaciones que remiten a construcciones culturales existentes acerca del país de origen, el color de la piel y la lengua o la religión y que se muestran en los significados que se dan a determinados estilos de vida, costumbres, formas de vestir, expresiones corporales, formas de hablar... (id.ib.:29).

Assim, a partir dessa constatação da importância das representações de gênero, classe e origem na articulação de distinções sociais discriminatórias que justificam as desigualdades sociais no contexto migratório, busquei os mecanismos através dos quais se constroem e/ou se reafirmam as representações sobre a mulher migrada nos audiovisuais analisados.

\section{As representações sobre as mulheres migradas nos audiovisuais analisados}

A partir dos audiovisuais: Trata de Blancas (1993), Quan la mare torna a casa per Nadal (1995), La Promesa (1996), Cuando dejé mi tierra (1996), Noies negres a la recerca d'una educació (1998), Dona, immigració i integració (1998), Flores de otro mundo (1999), Pan y Rosas (2000), Les dones immigrades desafiem la invisibilitat (2000), Domingo si Dios quiere (2001), Muso. Dones Subsaharianes i emigració (2001), Las mulheres de verdad tienen curvas (2002), Struggle (2003), Extranjeras (2003), O totes o cap (2003), María llena eres de gracia (2004), Si nos dejan (2004), Cuidados, Hogares y Fronteras (2004), Mujeres de Hoy: inmigración (2004), Trajectes invisibles. Les dones en les migracions. Materials audiovisuals per a les activitats de primària, secundària i formació permanent (2004), procedo a um estudo dos papeis atribuídos às personagens migradas, para dialogicamente construir uma análise sobre as representações que estes articulam sobre essas mulheres. Neste sentido, argumento que as representações sobre as mulheres migradas encontradas nos audiovisuais estudados refletem as diferentes maneiras como 
A representação audiovisual das mulheres migradas

emerge uma associação recorrente das migradas à indocumentação, à pobreza, à criminalidade, à ignorância, à maternidade obrigatória e numerosa, à prostituição, a dotes especiais para o cuidado da casa e dos outros, a uma ideia racializada e exoticizada (e por vezes sexualizada) de feminilidade, à passividade, à violência de gênero, etc.

A indocumentação é uma das situações mais presentes nos audiovisuais, não sendo, no entanto unívoca: enquanto, grosso modo, nos documentais, a referência à indocumentação se faz no marco da reivindicação de uma maior igualdade de direitos, nos filmes de ficção sua representação é mais ambígua. Em Trata de Blancas, La Promesa, Struggle e María llena eres de gracia, por exemplo, a situação de indocumentação (isto é, ausência de permissão de residência e trabalho na União Europeia) aparece associada à ilegalidade e à criminalidade.

Em María llena eres de gracia, Maria é uma jovem colombiana cujas relações com sua família e seu namorado são tensas e, depois de ter problemas também no trabalho, se demite. Maria está grávida, mas não quer se casar e decide ir procurar trabalho em Bogotá. Casualmente, ela se encontra com um conhecido (Frank) que se oferece para levá-la a Bogotá. No caminho, ele lhe faz uma proposta de transportar droga para os EUA e ela fica interessada no dinheiro oferecido. Em Bogotá, Maria conhece Lucy, que já fez a viagem com sucesso. Pouco depois, Maria, Lucy e Blanca embarcam rumo aos Estados Unidos transportando a cocaína. Durante a viagem, Lucy não se sente bem. Chegando aos E.U.A., Lucy piora e os receptores não querem levá-la ao hospital. No meio da noite, Maria desperta e vê os receptores desfazendo-se do corpo de Lucy. Assustadas, Maria e Blanca fogem juntas até a casa da irmã de Lucy, Carla, que vive em Nova York há anos. Carla as apresenta a Don Fernando, para ajudá-las a conseguir trabalho. Porque Blanca não é nada discreta, Don Fernando descobre toda a história. Maria e Blanca acabam devolvendo a droga aos receptores e recebem seu dinheiro. Depois do velório de Lucy, Maria e Blanca se preparam 
para voltar à Colômbia. No aeroporto, Maria deixa que Blanca embarque sozinha e fica nos E.U.A.

Assim, a representação da criminalidade aparece associada à pobreza, estimulando o tráfico de drogas. Nesse filme, ainda que possa haver distintas interpretações sobre a moralidade de Maria, talvez o mais correto fosse falar de uma combinação de fatores que a motivaram a participar do tráfico de drogas. $\mathrm{O}$ filme focaliza especialmente as razões econômicas da decisão de Maria, as quais são explicitamente marcadas na cena em que Frank lhe propõe levar cocaína para os E.U.A. Nesse sentido, a ideia de que a preocupação pelo futuro do seu filho é uma motivação relevante se insinua de maneira bastante mais sutil, através de um cartaz quase imperceptível presente no enquadre final do filme, que diz, em inglês: "O que importa é o que está dentro".

De maneira similar, em Trata de Blancas a migração também é considerada como consequência da pobreza do país de origem. Essa reportagem emitida pela televisão pública espanhola (TVE) sobre o tráfico internacional de mulheres com fins sexuais transcorre entre Bélgica, Holanda e República Dominicana, mostrando tanto o mercado ao qual se destinam essas mulheres, quanto ao lugar onde são recrutadas. $\mathrm{O}$ estilo se baseia na filmagem com câmera oculta em clubes noturnos europeus e no local do captador dominicano, assim como em entrevistas com extrabalhadores/as de clubes noturnos, captadores e inclusive um proprietário desses clubes. Nessa linha argumentativa, a prostituição aparece como fruto da credulidade das mulheres que caem nas propostas enganosas dos proxenetas, os quais se aproveitam da fragilidade da condição de indocumentadas. Infelizmente, o discurso da reportagem é parcial e deixa sem questionar a dureza da lei de migração que dificulta a obtenção da documentação pertinente e facilita a vida aos traficantes de pessoas e proxenetas.

Assim, uma vez que a pobreza se associa à representação da indocumentação discursivamente transformada "ilegalidade", facilmente associa-se as mulheres migradas à prostituição ou, em 
A representação audiovisual das mulheres migradas

outros casos, às relações por conveniência ou a comportamentos sexuais transgressores. Struggle é um exemplo do estabelecimento dessa relação. Nele, Eva, uma jovem polaca, trabalha de boia-fria nas plantações de morango na Áustria. Junto com um grupo de trabalhadores sazonais, Eva participa na colheita em condições duríssimas por salário miserável. Também traz consigo sua filha. Acabada a colheita, os trabalhadores são devolvidos ao país natal. No entanto, no momento de cruzar a fronteira, a protagonista $e$ sua filha fogem para poder continuar na Áustria. Cada manhã, a jovem vai a um ponto onde espera que apareçam recrutadores para trabalhos eventuais. Um dia, nesse ponto de recrutamento, aparecem dois homens fingindo serem recrutadores: na verdade são policiais e todos/as os presentes fogem. Neste ponto o filme realiza um giro. Abandona por completo a história da jovem $e$ começa a contar a de um homem austríaco de meia-idade. Divorciado, tem uma filha a quem vê esporadicamente e com quem tem uma relação interpessoal insatisfatória. A esposa se encontra numa residência geriátrica e, quando vai visitá-la, nem sequer se falam. Enquanto isso, ele busca prazer em práticas sexuais "bizarras", como simular seu próprio enforcamento. Um dia, ele pergunta a sua filha se ela tinha gostado de sua namorada. Em seguida, vê-se o personagem fazer uma mala com um vibrador e mais tarde aparece num local de encontros, onde há vários voyeurs olhando por buracos nas paredes. Então, este aparece junto à cama, também olhando, sentado atrás das duas garotas que estão oferecendo o espetáculo: uma penetrando a outra com um dildo. Ele então agarra a que está penetrando pela cintura e a ajuda a fazê-lo, e a câmara então nos revela que se trata de Eva. Depois disso, o filme acaba com o casal comprando uns sapatos para a filha de Eva.

Assim, a sexualidade da mulher migrada, ao ser associada a uma situação de pobreza, é considerada como fora da norma. Até em filmes mais engajados, opta-se por uma explicação do trabalho sexual como consequência da situação desesperada em que a migrada se encontraria ao chegar a um país estrangeiro: em Pan y 
Rosas, por exemplo, Rosa revela que se havia prostituído para enviar dinheiro à família. Nesse filme de Ken Loach, conhecido cineasta militante, Maya é uma jovem mexicana que entra clandestinamente nos E.U.A. para encontrar-se com sua irmã, Rosa. Esta trabalha na limpeza de um edifício e consegue um trabalho para Maya no mesmo lugar. O trabalho na limpeza do edifício é precário e mal remunerado e, depois de conhecer um jovem sindicalista, Maya e seus companheiros de trabalho começam a mobilizar-se para reivindicar seus direitos. No entanto, os empregadores pressionam e há uma série de demissões e, em uma manifestação, a polícia detém Maya e seus companheiros. Na prisão, recebem a notícia de que vão ser readmitidos. Não obstante, a polícia averigua que Maya não tem visto e a deportam.

Pan y Rosas é um dos poucos filmes que mostram uma migrada mobilizando-se politicamente e manifestando-se pelos seus direitos. Porém, essa militância não é espontânea e surge da intervenção de um jovem sindicalista estadunidense para motivar a ação das personagens femininas, que até então se submetiam bastante resignadamente à exploração de seu trabalho. Como não podia deixar de ser, Maya e seu sindicalista formam um par romântico precocemente separado pela intervenção policial, numa relação inconclusa típica no âmbito das relações interétnicas no cinema (Santolalla, 2005).

Já La Promesa se destaca por representar a mulher migrada como um ser extremadamente passivo e submisso. Nesse filme, a mulher negra muçulmana é caracterizada como uma pessoa carente de autonomia e subordinada ao protagonista masculino, desempenhando um papel tradicional condicionado pela domesticidade, maternidade e religiosidade. 
A representação audiovisual das mulheres migradas

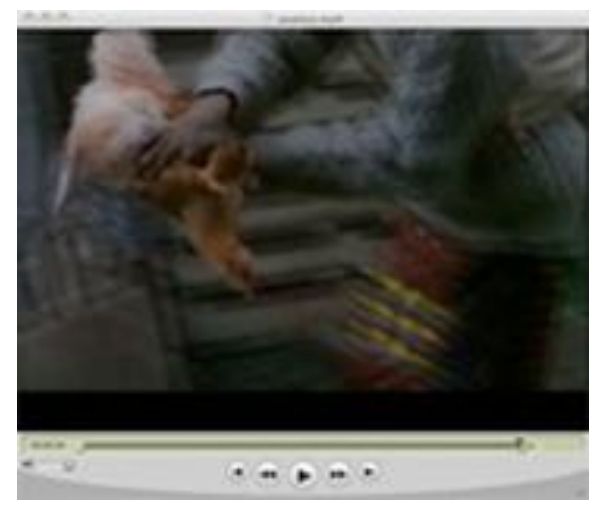

http://dl.dropbox.com/u/47943088/exotico.mp4

Em La Promesa, Roger é um homem que, ajudado por seu filho Igor, utiliza a vulnerabilidade dos/as migrados/as em situação de irregularidade para fazer negócios. Um de seus trabalhadores, Hamidou, acaba de trazer à Bélgica a esposa, Assita, junto com seu bebê. Quando um inspetor se apresenta inesperadamente para fiscalizar a construção em que trabalha Hamidou, este cai de um andaime, ficando gravemente ferido. Moribundo, ele faz com que Igor lhe prometa que protegerá sua esposa e filho se ele morrer. Para evitar problemas, Roger e Igor acabam por enterrar Hamidou na própria obra. Com o passar dos dias, Assita começa a inquietar-se com o desaparecimento de seu marido. Para livrarse de Assita, Roger planeja vendê-la a uma rede de prostituição. Porém, Igor se rebela e "salva" Assita e seu filho do plano de Roger. Igor se oferecerá então para "ajudar" Assita a procurar Hamidou. Assim, o filme se desenvolve ao redor dessa busca, em que o jovem é o sujeito ativo. Assita segue na ignorância do destino de seu marido, e Igor, transformado em seu "benfeitor", a ajuda a fugir de Roger, sempre tentando convencê-la a ir atrás de uns parentes que ela tem na Itália. Só ao final do filme a mulher assume um papel menos subordinado, quando seu "benfeitor" finalmente lhe revela que seu marido morreu. 
O tratamento dado ao personagem de Assita em La Promesa é visivelmente vitimizante, racializante e exoticizante. Assita é associada à domesticidade, à passividade, à submissão $e$ a um papel exclusivamente maternal $e$ familiar. Não tem quase nenhuma ação própria, tudo que faz é para seu filho ou marido $e$ não parece nada interessada na sociedade receptora ou no que passa a seu redor. Assim, a migrada negra é vista como alheia a qualquer "integração" $e$ suas supostas características são apresentadas como sinônimos de atraso e ignorância, marcando o contraste com a feminilidade desejável no "ocidente".

Adicionalmente, La Promesa, sugere uma sexualização da "raça". A mulher negra, em uma posição de poder subordinada, é claramente um objeto de desejo sexual, característica que comparte com o filme Flores de otro mundo, de Iciar Bollaín. Não obstante, o fazem desde uma perspectiva radicalmente diferente, uma vez que a diretora de Flores de otro mundo é uma militante feminista de longa data e seu olhar é bastante crítico e irônico. Em Flores de otro mundo, três personagens femininas se destacam: Patrícia, Marirrosi e Milady. As duas primeiras chegam juntas a Santa Eulália, uma cidadezinha onde não há mulheres jovens, numa caravana organizada pelos homens do lugar. Já Milady é trazida de Cuba por Carmelo, um homem rico que viaja com regularidade à ilha. Através das relações sentimentais estabelecidas por essas personagens são mostrados alguns dos conflitos $e$ negociações que devem realizar essas mulheres migradas: a expectativa do cumprimento de um papel feminino tradicional, a falta de autonomia, a rejeição por parte de setores da sociedade receptora, a violência doméstica, a sexualização etc.

\footnotetext{
${ }^{6}$ Não utilizo o termo integração no sentido assimilacionista de que as migradas deveriam adotar "a cultura" do país receptor (como se essa fosse homogênea $e$ que não existissem diferentes culturas, frequentemente conflitivas entre si, no âmbito dos limites fronteiriços de um Estado-Nação). Pelo contrário, tento abordar o espaço de participação dessas agentes na sociedade civil e o modo como lidam com as restrições que encontram em decorrência da condição de cidadania burocraticamente reduzida.
} 
A representação audiovisual das mulheres migradas

Assim, enquanto em La Promesa observa-se o desejo voyeurístico projetado sobre uma mulher negra fundamentalmente passiva, em Flores de otro mundo, a personagem de Milady é uma "mulher fálica"7, ativa e não vinculada a um papel maternal e familiar, motivo pelo qual é constantemente vista como um objeto sexual.

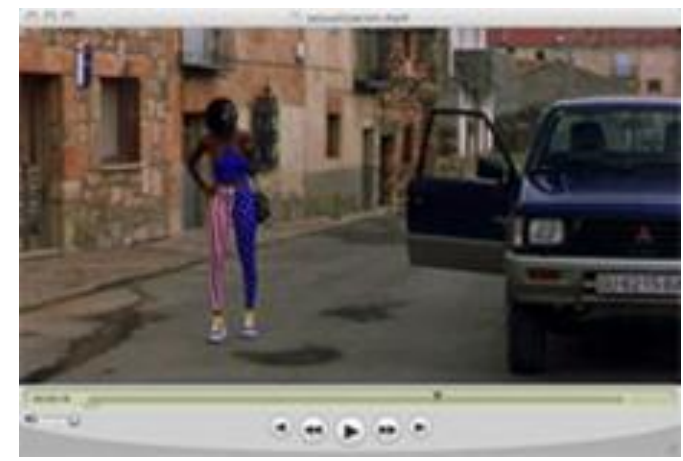

http://dl.dropbox.com/u/47943088/sexualizacion.mp4

Nesse sentido, argumento que o tratamento da sexualidade da mulher migrada também aparece associado como pertencente ao âmbito do "tradicional". Isto é particularmente claro com respeito à religião: nos diversos audiovisuais, todas as muçulmanas representadas são associadas a um papel maternal $e$ familiar. Já a representação da relação das latino-americanas com a maternidade e a sexualidade se dá mais em termos da oposição "tradicional" versus "moderno" que de religião (ainda que também sejam representadas como bastante católicas). De um modo geral, comparadas às personagens muçulmanas, as protagonistas latino-americanas têm um papel bastante mais ativo, inclusive sexualmente. Porém, apesar dessa atividade, não deixam de estar associadas a uma feminilidade amável e piedosa (ou ao

7 Um dos papéis femininos "clássicos" especialmente presente no cinema negro norte-americano. Trata-se de mulheres ativas, mas cuja atividade é necessariamente castigada por inadequada e subversiva. 
menos mais "suaves" que a "dominatrix" polaca "Eva" de Struggle). Nesse sentido, alguns traços presentes nos filmes María llena eres de gracia e Las mujeres de verdad tienen curvas associam simbolicamente as protagonistas femininas com a representação da Virgem Maria, como é sugerido pelo próprio título do filme María llena eres de gracia.

Em Las mulheres de verdad tienen curvas, Ana é uma adolescente filha de mexicanos migrados nos EUA que está concluindo a escola secundária e acaba de demitir-se de seu trabalho. Embora seu desejo seja ir à universidade como seus companheiros de classe, sua realidade econômica e familiar não contribui à realização desse sonho. A mãe de Ana, Carmen, é uma mulher tradicional que crê nos valores patriarcais, no trabalho duro e no dever para com a família. As relações entre Carmen e Ana não são as melhores. Ao descobrir que Ana se demitiu, Carmen a obriga a ir trabalhar no ateliê de costura de sua irmã. No atelie de costura de Estela, Ana descobre a dureza do trabalho precário realizado por um grupo de mexicanas para as elegantes boutiques de Los Angeles. Apesar de se ver imersa nessa realidade, tão distante de seus sonhos de uma educação e uma vida melhor, Ana se inscreve para uma bolsa de estudos e é admitida. No entanto, Carmen a dissuade ao chantageá-la emocionalmente dizendo que isso seria abandonar a família. Assim, Ana segue trabalhando no ateliê. Passa por um processo que vai desde a rejeição a essa condição social até a aceitação e o reconhecimento do valor do seu corpo e do seu trabalho. Nessa trajetória, Ana descobre o sexo, apoia a sua irmã e enfrenta definitivamente a sua mãe, que finalmente é forçada a encarar a partida de sua filha para Nova York. Assim, narrativamente, a personagem de Ana corresponde ao arquétipo do "desvalido triunfante", uma pessoa que, apesar das dificuldades de sua condição social, consegue superar os obstáculos e alcançar seus objetivos. 
A representação audiovisual das mulheres migradas

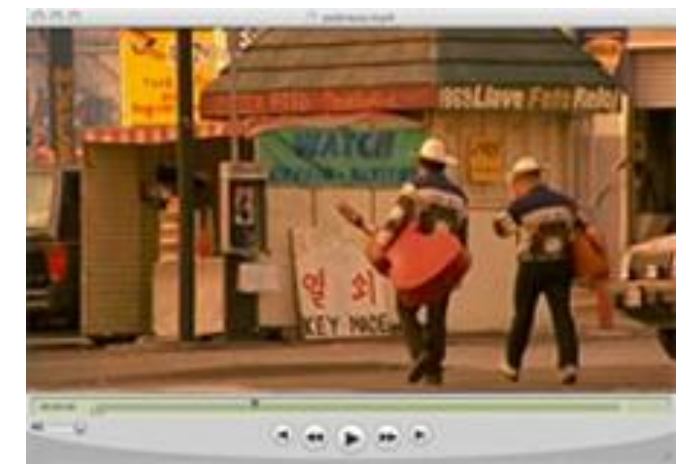

http://dl.dropbox.com/u/47943088/sexualizacion.mp4

Dessa forma, o papel consideravelmente ativo de personagens sul-americanas como Ana ou Maria contradiz em parte a representação geral de passividade e de vitimismo que costuma ser associada à mulher migrada. Porém, somente essas heroínas de inclinações mais ternas chegam a alcançar seus objetivos: personagens como Milady ou Lucy, que correspondem à figura da "mulher fálica", inevitavelmente sofrem as consequências de sua atividade (com um final trágico ou infeliz).

A violência de gênero é abordada tanto em Flores de otro mundo como em Domingo si Dios quiere e aparece como uma punição pela agência das personagens que, em lugar de se contentarem em serem objetos para seus companheiros, decidem ter elas mesmas vida própria. Em Domingo si Dios quiere, Zouina é uma mulher argelina cujo marido vive na França há muitos anos. Com a abertura da política migratória francesa de reagrupação familiar, Zouina embarca com seus filhos e sua sogra (Aïcha), rumo a França. A chegada de Zouina na França começa mal: se envolve em uma briga com uma vizinha e acaba recebendo a visita da polícia. Aïcha aproveita o episódio para envenenar a relação entre Ahmed e Zouina, afirmando que esta se comportou de maneira indecente, o que acaba na primeira cena de violência de gênero do filme. Zouina passa os dias fechada em 
casa com a sogra e seus únicos contatos com o mundo exterior são o rádio e sua amizade com Nicole, uma vizinha divorciada. Com a proximidade da festa do cordeiro ${ }^{8}$, Zouina deseja encontrar uma família argelina com quem possa comemorar a data. Aproveitando as ausências de Ahmed e Aïcha para buscar um cordeiro, Zouina sai escondida de casa com seus filhos para procurar essa família. Depois de umas quantas aventuras, Zouina finalmente encontra a família argelina. Para sua decepção, Zouina se encontra com uma mulher muito mais conservadora que ela, $e$ que a acaba expulsando de sua casa. Zouina arma uma cena de desespero na porta da casa dessa família. Ao chegar em casa, seu marido e a sogra a esperam. A sogra começa com suas queixas, mas desta vez Ahmed a manda calar. Zouina lhe sorri e diz que começará a levar as crianças ao colégio.

No caso de Domingo si Dios quiere, a representação da violência de gênero acaba por contribuir com a criminalização dos homens migrados (Pérez, 2008): Ahmed é um migrado muçulmano machista e violento. Não é dizer que esses não existam, no entanto, essa representação corresponde em grande medida aos estereótipos correntes sobre migrados e muçulmanos. Já em Flores de otro mundo, o agressor é um espanhol. Aqui se rompe o estereótipo de que as agressões a mulheres migradas são causadas somente por seus companheiros, também estrangeiros, que viriam de culturas machistas e atrasadas e que ainda não se haveriam "integrado" na "cultura esclarecida" do país receptor. Carmelo, além do mais, é de uma classe privilegiada, quebrando outro estereótipo de que só há violência de gênero nas classes desfavorecidas. O que Flores de otro mundo mostra é que a violência de gênero está relacionada com as relações de poder: um homem poderoso se concede o direito de controlar a vida de

8 Cabe dizer que nos dois filmes em que há personagens muçulmanas aparece a figura do cordeiro (Assita chega a criar um cordeiro em meio a obra onde trabalhava seu marido). Num determinado sentido, esse é uma metáfora da passividade atribuída a essas mulheres, além de um reforço da leitura dessas, sempre e incansavelmente, a partir da religião. 
uma mulher que depende dele economicamente.
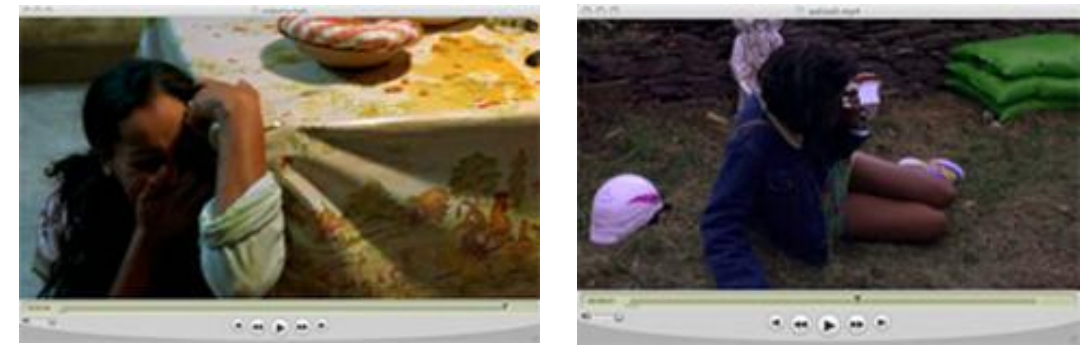

http://dl.dropbox.com/u/47943088/violencia.mp4 e http://dl.dropbox.com/u/47943088/paliza0.mp4

Finalmente, cabe dizer que as protagonistas migradas, em geral, têm uma representação mais positiva que os personagens secundários de origem migrada. Em primeiro lugar, frequentemente se atribuem papéis antagonistas a outras/os migradas/os (Carmen, Rosa, Ahmed, Aïcha, por exemplo), e não a autóctonos/as. Isso significa que o conflito da trama normalmente ocorre entre estrangeiros, fato que: 1) pode transmitir uma imagem das pessoas migradas como problemáticas e conflitivas; 2) representa uma tendência a apresentar os/as autóctonos/as como pessoas solidárias e pacíficas (como o sindicalista ou Nicole $e^{9}$ e 3) desloca os conflitos entre migrada/os e autóctona/os a instâncias impessoais, como a polícia ou a pessoas muito corruptas $e$ ambiciosas (como Roger ou o chefe de Maya ${ }^{10}$ ). Em segundo lugar, a representação desses personagens costuma associá-los à ignorância. Embora esta possa tomar também várias formas, sugiro que, de uma maneira geral, a representação da ignorância aparece associada à pertença ao âmbito do "tradicional". Os personagens, quanto mais aparecem como representantes do

9 Personagens de Pan y Rosas y Domingo si dios quiere.
${ }^{10}$ Personagens de La Promesa y Pan y Rosas, respectivamente. 
"tradicional" (Carmen, Rosa, Ahmed, Aïcha) ${ }^{11}$, mais se insinuam como de mentalidade limitada, o que se acentua especialmente na representação dos personagens muçulmanos.

Já nos audiovisuais como Noies negres a la recerca d'una educació e Si nos dejan, temos a versão das/os migradas/os sobre os fatos, revelando a discriminação tanto no âmbito educativo como laboral baseada nessa imagem das/dos migradas/os como pessoas retrógradas e sem formação. Em Noies negres a recerca d'una educació, reportagem televisiva da $\mathrm{BBC}$ sobre a experiência da educação multicultural numa cidade inglesa, as protagonistas são quatro jovens de origem "asiática" ${ }^{12}$ (na verdade pertencem a uma minoria étnica ao norte da Índia), que, a partir de entrevistas e/ou dramatização, expõem suas dificuldades no sistema educativo britânico. Por um lado, se queixam duma educação paternalista a qual se pretendia multicultural, por outro, agora se encontram com um sistema educativo elitista para o qual simplesmente não existem, enfrentando com uma série de preconceitos que atribuem às mulheres "asiáticas" um papel submisso e doméstico incompatível com a ambição de fazer estudos universitários.

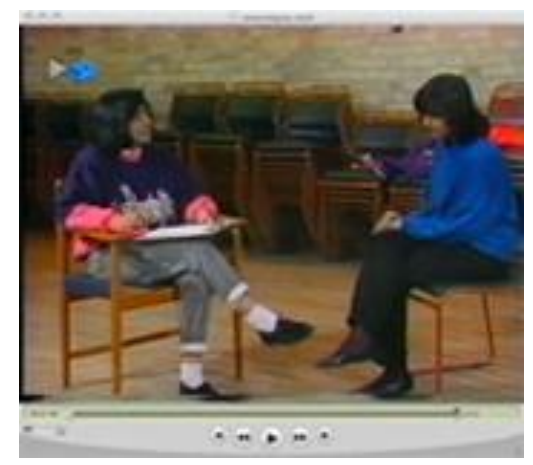

http://dl.dropbox.com/u/47943088/noiesnegres.mp4

\footnotetext{
${ }^{11}$ Personagens de Las mujeres de verdad tienen curvas, Pan y Rosas, Domingo si dios quiere e La Promesa, respectivamente.

${ }^{12}$ Note-se a excessiva generalização decorrente desse termo.
} 
Já Si nos Dejan é um documentário que transcorre basicamente entre os relatos de seis migrados/as que vivem em Barcelona. O primeiro, Andrei, é ucraniano. Chegou à cidade depois de várias tentativas de entrar em distintos países da União Europeia, tendo, inclusive, sido preso no Reino Unido. Mari Carmen é venezuelana, filha de espanhóis. Em Barcelona trabalha como garçonete e explica que veio de Venezuela após uma separação. Nana vem de Mali e quase não fala espanhol. Explica que veio até a Espanha em canoa, desde Marrocos, perseguindo o sonho de uma Europa rica e próspera. Caia é filha de catalães que emigraram para a Argentina e, depois, fugindo da ditadura, foram aos E.U.A.. Ben é norte-americano e está em Barcelona faz dois anos, realizando um tratamento médico que não podia pagar em seu país. E, finalmente, Ana, é a diretora-personagem, construindo o documental entre a narração de eventos de sua vida e os relatos de outros migrados/as. Este documentário auto-reflexivo trata basicamente da discriminação, que é narrada reiteradamente pelos personagens em diversas histórias sobre sua entrada em Espanha, os trâmites dos papéis, a busca de trabalho, os conflitos ao redor da língua, os sotaques etc. Para alguns, como Ben, a discriminação é positiva e os finais são felizes, mas para Nana, o futuro é incerto e o sonho de Europa um sonho desfeito.

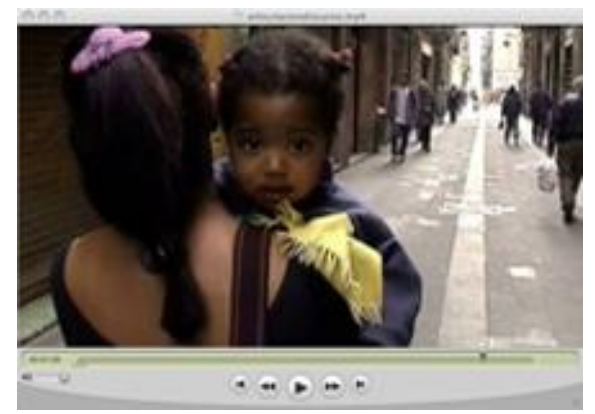

http://dl.dropbox.com/u/47943088/articulaciondiscurso.mp4 
Embora em muitos dos audiovisuais analisados a passividade apareça relacionada com aspectos vitimizantes na representação das mulheres migradas, existem outras maneiras de enfocar essa imagem. Muso. Dones Subsaharianes i emigració explica como a migração afeta a vida das mulheres senegalesas na sociedade catalã. Por exemplo, contrariamente aos seus costumes tradicionais de vida em comunidade, quando essas mulheres migram para reagrupar-se com seus maridos em Catalunha, se encontram isoladas em consequência do individualismo e do modelo de família nuclear burguesa da sociedade receptora. Destaca-se também o papel delas na educação dos filhos: na Catalunha, a responsabilidade pela educação passa a ser exclusiva das mulheres (sem o apoio da família extensa ou comunidade) e existe uma tensão entre a escolha de uma educação europeia ou a manutenção da cultura de origem. $O$ final do audiovisual denuncia o status legal inferior a que estão obrigadas as mulheres que migram por reagrupação familiar: sua documentação lhes autoriza a residência, mas não lhes permite trabalhar, pelo que só lhes resta a opção de depender economicamente de seus maridos, ou verem-se forçadas a submeter-se ao trabalho irregular em condições precárias. Assim, esse audiovisual denuncia a passividade e a domesticidade que a legislação impõe a essas mulheres, as quais se encontram forçadas a obedecer ou transgredir essa condição de gênero que lhes é imposta.

Assim, em Muso... fica claro que os supostos "dotes especiais" para o cuidado da casa e dos outros "tipicamente femininos" associados às migradas, mais do que uma característica própria destas, corresponde é ao lugar que lhes atribuem na sociedade receptora e aos papéis que se espera que desempenhem. Ainda assim, embora nesse audiovisual se reivindique a importância da mulher no país de origem, pouco se diz da importância dessas mulheres na (e para a) sociedade receptora à parte da educação dos seus próprios filhos. Elas aparecem como reagrupadas que desenvolvem basicamente um papel maternal e familiar, e é só já quase ao final do audiovisual 
que as mulheres deixam claro que também trabalham fora de casa (ainda que isso seja "ilegal" no caso da reagrupação familiar). No entanto, não se mostram essas imagens das migradas como trabalhadoras.

Por outro lado, um audiovisual em que se observa claramente imagens das migradas como trabalhadoras é Quan la mare torna a casa per Nadal. Nele, depois de oito anos de ausência, Josie, empregada doméstica na Grécia, volta a sua terra natal no Sri Lanka para passar o Natal em família. Seus três filhos esperam sua chegada e os conflitos de uma família deslocalizada afloram: ainda que o filho mais velho se beneficie do dinheiro enviado pela mãe, a filha de Josie, que agora se casa, se sente abandonada $e$ inclusive tentou suicidar-se, enquanto o caçula tem problemas de comportamento na casa de seus tios e na escola. Quan la Mare Torna a Casa per Nadal explica, através da história de Josie, como as mulheres se converteram no principal produto de exportação do Sri Lanka, mostrando, de uma parte, o papel de trabalhadora migrada da protagonista e, de outra, a pressão pela manutenção de sua família no seu país de origem. Também questiona a "liberação" das mulheres, demonstrando que, muitas vezes, isto significa a transferência do trabalho doméstico das mulheres ocidentais de classes favorecidas a outras mulheres mais pobres (muitas vezes privadas de poder garantir as tarefas em suas próprias casas). 


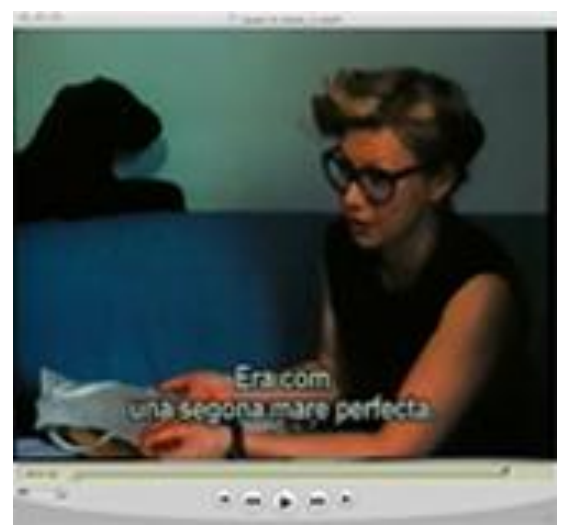

http://dl.dropbox.com/u/47943088/quan la mare_1.mp4

Assim, esse documentário deixa claro que, na verdade, o que essas mulheres têm é necessidade de trabalhar e dispor de uma renda suficiente para manter sua família no país de origem, enquanto as mulheres europeias necessitam dessa mão-de-obra para que possam elas, por sua vez, trabalhar fora de casa. Outro audiovisual que deixa clara essa posição é Cuidados, Hogares y Fronteras. Esse audiovisual, em conjunto com um livro do mesmo nome, é o resultado do projeto transnacional "Servicio doméstico y de cuidado: estratégias de conciliación y condiciones de empleo en diferentes unidades familiares. Desigualdades de género, clase $y$ etnia". ${ }^{13}$ Nele, se intercalam entrevistas com quatro mulheres migradas de distintas origens e suas respectivas empregadoras nos diferentes países receptores que participam do projeto. As migradas são de Ucrânia, Peru, Brasil e Sri Lanka e as empregadoras da Áustria, Espanha, Alemanha e Reino Unido. Enquanto as migradas reclamam seu direito a um trabalho digno e

\footnotetext{
${ }^{13}$ Promovido e coordenado pela Cruz Vermelha Espanhola e financiado pela Comissão Europeia. Participaram como sócias nesse projeto: o Instituto de Investigações Feministas da Universidade Complutense (Espanha), Maiz (Áustria), a Universidade de Hamburgo (Alemanha) e Bradford Youth Development (Reino Unido).
} 
em condições legais normais, suas empregadoras reivindicam o direito a trabalhar fora de casa e conciliar esse trabalho com o trabalho doméstico e a vida familiar, reclamando estruturas estatais para cuidar dos familiares dependentes, sejam crianças ou idosos.

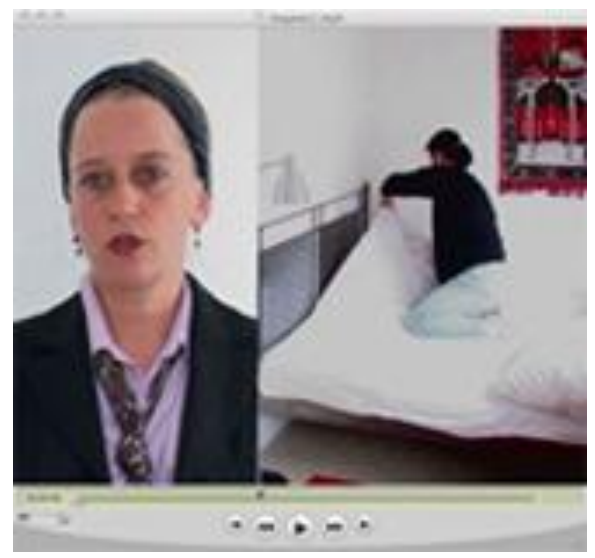

http://dl.dropbox.com/u/47943088/hogares1.mp4

Nesse audiovisual, sem embargo, embora se visibilize essa crítica, o tom geral sublinha a harmonia entre as mulheres, de maneira que não desmascara de todo as condições de exploração a que frequentemente se encontram submetidas as trabalhadoras nos serviços domésticos. Essa relação de subalternidade só é mencionada em um dos relatos, em que a afirmação explícita de uma posição de classe da empregadora se complementa com o trato invisibilizante dispensado à trabalhadora doméstica.

Por sua vez, existem distintos tipos e níveis de exotização das mulheres migradas nos audiovisuais estudados. Dona, immigració i integració, por exemplo, é realizado a partir da perspectiva de uma sociedade receptora que contempla migrados/as, quase que exclusivamente, desde um ponto de vista laboral ou de problemáticas sociais como aquelas relacionadas ao 
acesso à habitação e à formação de bairros "conflitivos". Emitido pela televisão espanhola, esse audiovisual, contém duas partes. A primeira é uma reportagem em que se apresentam os relatos de cinco protagonistas de diferentes países que vivem em Barcelona. Essas mulheres explicam suas motivações para haver emigrado, falam sobre seus países de origem, sua situação laboral atual e o que pensam de Barcelona. Na segunda parte, se realiza uma mesa redonda sobre "imigração" e integração das mulheres migradas. $\mathrm{O}$ debate parte do pressuposto da tripla discriminação (de gênero, classe e "raça"), posição que é resumida (de maneira reducionista) na afirmação da moderadora de que as migradas são pobres, estrangeiras e, além do mais, mulheres. Posteriormente, a moderadora defende a posição de que há um processo de formação de "ghettos" em Ciutat Vella", o que provoca uma considerável tensão no debate: nele, as entrevistadas (todas pesquisadoras e profissionais qualificadas estrangeiras) tentam dar a conhecer a diversidade da realidade da migração feminina, assim como as situações de exclusão social vividas pelos distintos coletivos, sem cair no reducionismo marginalizante expressado em distintos momentos pela apresentadora.

Uma abordagem bem menos reducionista é a de Cuando dejé mi tierra. Este programa, emitido pela televisão pública espanhola (TVE), apresenta um platô de estúdio com um banquinho, onde várias mulheres de distintas nacionalidades se sucedem na explicação do seu processo migratório. As entrevistadas explicam porque migraram e falam de uma série de experiências de vida diferentes e dificilmente homogeneizáveis. Dessa maneira, se mostra toda classe de motivações muito distintas da razão econômica predominantemente considerada como a causa das migrações. Além disso, as migradas apresentam uma atitude identitária distinta daquelas que normalmente são tipificadas como as "identidades migradas": em que, ou bem atribuem a essas pessoas uma pertença inquestionável a seu país

${ }^{14}$ Centro Histórico de Barcelona. 
A representação audiovisual das mulheres migradas

de origem, ou bem são consideradas alheias a qualquer "cultura" (como denotam as habituais frases feitas "nem daqui nem de lá", "presas entre duas culturas", etc.). Também esteticamente se nota a mão da realizadora Lulú Martorell, conhecida por sua produção alternativa. Além disso, esse programa é pioneiro também no sentido em que é o mais antigo dos audiovisuais analisados produzidos em Espanha.

Somente oito anos depois se produziria Mujeres de Hoy: inmigración, audiovisual pertencente a uma coleção editada pelo Instituto de la $\mathrm{Mujer}^{15}$, que traça um panorama das mulheres atualmente em âmbitos distintos como o esporte, o meio rural ou, nesse caso, a "imigração". Mujeres de Hoy proporciona um breve relato sobre a experiência da chegada dessas mulheres à Espanha, a dificuldade da língua, a precariedade da habitação e a quase impossibilidade do acesso a um trabalho que não seja no serviço doméstico, no cuidado de idosos/crianças ou no setor dos serviços. Também se tratam temas como a perda de um meio conhecido e a saudade da família, a ambivalência entre o desejo e a identidade e entre ficar e voltar ao país de origem. Quanto à integração, se relata a dificuldade de estabelecer relações num meio em que essas são regidas por outra sociabilidade e na qual ser migrada/o é visto negativamente. Assim, ainda que o conteúdo deste audiovisual seja correto, é lamentável o conservadorismo estético, o que faz com que, apesar do potencial de sua mensagem, seu conjunto seja excessivamente institucional.

Finalmente, Extranjeras é um documentário de longametragem que busca dar a conhecer um pouco das "outras culturas" através da experiência de várias migradas que vivem em Madri: mostram-se seu ambiente familiar, suas atividades de tempo livre, no que trabalham etc. Descobrimos também os novos espaços de intercâmbio, relação e encontro que criaram, e como

${ }^{15} \mathrm{O}$ Instituto de la Mujer é um organismo autônomo dependente do Ministerio de Igualdad, através da Secretaría General de Políticas de Igualdad do governo espanhol. 
se adaptam ao novo meio. $\mathrm{O}$ filme começa com uma sequência de entrevistas a mulheres migradas agrupadas por países de procedência: China, Sri Lanka, Romênia, Polônia, Equador etc. Fala-se de integração, de educação, de tradição e mudança, do papel das mulheres na sociedade, dos motivos da migração, de identidade, da perseguição aos "sem papeis"16 e suas práticas "ilegais" (venda ambulante, por exemplo), de racismo etc. Observam-se distintas maneiras de encarar o projeto migratório e o novo meio, diferentes maneiras de constituir uma identidade e de relacionar-se com as origens. Aprofunda-se um pouco na convivência de algumas das personagens; não obstante, o audiovisual segue buscando novas protagonistas, outras nacionalidades, até o fim, quando, depois de apresentar três cantoras, termina com uma festa que reúne todas as entrevistadas. Apesar dos seus méritos, nesse filme nota-se como a representação das mulheres migradas segue as linhas gerais da "nossa" percepção delas e suas culturas: as chinas discutem a tradição, as negras são cabeleireiras ou cantoras, as muçulmanas discutem o uso do véu e o machismo. Embora alguns desses temas pareçam ser tratados justamente numa tentativa de superar os estereótipos ou de "dar voz" às migradas para que expressem o que pensam sobre como são vistas pela sociedade receptora, temse a sensação de superficialidade e de que falta o contraponto de uma atitude diferente daquela esperada pela "nossa" visão desses coletivos. Nesse sentido, Extranjeras é um documentário construído com o valor de abordar muitos personagens, grupos e temas, mas sem chegar a desenvolver nenhum em profundidade $e$, consequentemente, a não questionar realmente os estereótipos.

De uma maneira geral, junto a essas representações mais frequentes, existem também estilos recorrentes através dos quais estas se articulam. Nesse sentido, as estratégias de representação audiovisual utilizadas se encontram relacionadas com o conteúdo das representações. Considerando-se particularmente as

${ }^{16}$ Veja-se Rodrigo (2006:163). 
A representação audiovisual das mulheres migradas

reportagens e documentários, percebe-se que muitos deles (especialmente os televisivos) se desenvolvem ao redor de umas convenções formais e argumentativas bastante ancoradas numa concepção renascentista da imagem como testemunha da realidade. Essa preocupação com o status de verdade do documental define em grande medida as orientações estilísticas/metodológicas dos audiovisuais, manifestando-se frequentemente pelo uso de elementos como a voz em off, a entrevista tipo "busto parlante", o predomínio do discurso verbal sobre o visual, etc.

Entre outros, Noies negres a recerca d'una educació, se desenvolve bastante dentro da linha de uma modalidade expositiva (Nichols, 1991), seguindo um estilo pedagógico bastante influenciado pelo modelo estabelecido por Grierson. ${ }^{17}$ A voz em off discorre sobre o tema e cobre os possíveis interstícios das entrevistas, conduzindo-nos na interpretação do conteúdo $e$ deixando pouco espaço para a ambiguidade, a expressividade ou dramaticidade. Apesar da sobriedade e convencionalismo do seu estilo, a reiteração recíproca entre a voz off e as entrevistas etc., Noies negres a recerca d'una educació, também possui umas características contrárias às da maioria dos representantes desse estilo de representação, que normalmente não deixam que seu "objeto" de exposição fale: nesse, as jovens falam não só nas entrevistas, mas também se confrontam com os responsáveis dos programas educativos a que se submetem, assim como dramatizam entre elas as situações de exclusão no sistema educativo que haviam explicado na entrevista convencional. Não obstante, se comparamos esse material com $O$ totes o cap, fica claro que a "voz" das jovens "asiáticas" é bastante mediada pelo discurso da voz em off e demais agentes institucionais.

\footnotetext{
${ }^{17}$ Influente membro do "General Post Office" britânico que definiu o cânone estético-estilístico maioritário do gênero documentário, cujo objetivo era “...establecer cierta imagen del documental como "utilitario, pedagógico e impersonal"..." (Weinrichter, 2004:31).
} 
O totes o cap é uma exceção quanto ao anteriormente dito sobre o apego às convenções "realistas" do documentário. Nesse, um grupo de jovens de diferentes países se reúne para fazer teatro como um meio de reflexão sobre sua experiência como migradas. $\mathrm{O}$ audiovisual mostra o processo de criação da peça, os ensaios, discussões e também algo da vida pessoal das protagonistas. A partir desse processo, o audiovisual trata da busca identitária dessas garotas, de seus ideais e dificuldades. A câmera passa de mão em mão entre essas jovens, ainda que pareça estar mais tempo nas mãos de Laura ou da equipe profissional de gravação (sua equipe de direção, entre outros trabalhos, se encontra relacionada a um importante festival de cinema e direitos humanos). Assim, esse audiovisual se aproxima mais às formas auto-reflexivas de realização audiovisual e utiliza, combinada com o trabalho de uma equipe profissional, a auto-representação. Por exemplo, num intervalo em que uma das jovens realiza uma entrevista com a outra, nota-se uma empatia muito maior que a habitual, como pode se deduzir do recurso constante a um primeiríssimo primeiro plano (muito raro ou simplesmente ausente nos outros materiais). Apesar de haver algumas falhas técnicas na entrevista (como tremores de câmara e ausência de correções de enquadramento quando necessárias), a intensidade do relato resulta beneficiada. Nesse estilo audiovisual, privilegia-se a proximidade, a subjetividade e a intensidade poética e emocional (todo o contrário do "modo expositivo" e sua neutralidade $e$ objetividade). Assim, potencia-se uma maior identificação do público com os sujeitos. 


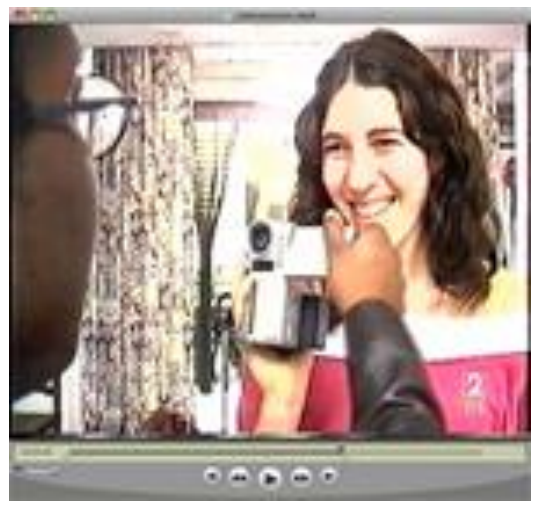

http://dl.dropbox.com/u/47943088/intervencion.mp4

Outro audiovisual que utiliza a auto-representação é Les dones immigrades desafiem la invisibilitat. Esse audiovisual é produzido por um grupo de migradas vinculadas ao movimento de mulheres de um bairro de Barcelona. Com o propósito de reivindicar a especificidade da migração feminina, mulheres de diferentes nacionalidades mostram os diversos papéis que exercem no dia-a-dia: seja buscando aprender a produzir um audiovisual, ou participando com suas experiências de vida e seus questionamentos sobre a sua condição. É um audiovisual bastante menos produzido que os demais e por este motivo se vê obrigado a suprir essas deficiências com alguns recursos formais conservadores como os títulos e cortinas (que dividem o vídeo em subtemas e preenchem lacunas de edição). No entanto, seu valor, como iniciativa, desde o próprio coletivo e seu caráter reivindicativo é inquestionável.

Por outro lado, um audiovisual que utiliza com habilidade a identificação do público com os sujeitos é Trajectes invisibles. Les dones en les migracions. Esse material didático, produzido por Dracmàgic (uma das entidades de onde se extraíram os fundos audiovisuais) está formado por dezoito fragmentos curtos de dezesseis filmes. Tratam de uma diversidade de temas: enquanto o 
primeiro, de Código desconocido (2000), mostra o retorno (temporal?) de uma migrada à casa, nos três seguintes (Rocco y sus hermanos (1960), Surcos (1951) e Españolas en París (1971)) vê-se a chegada de migradas/os italianas/os e espanholas/es a seus respectivos destinos, seja uma grande capital de seu próprio país ou de outro. Os seguintes fragmentos, ainda que bastante diversos em seus subtemas, tratam de maneira geral das relações interétnicas. Assim, enquanto Blue in the face (1995) apresenta uma série de pessoas de distintas etnias falando do caráter multiétnico de seu bairro, o Brooklyn, em Las afinidades electivas (2001) discute-se o tema da discriminação pela origem e do uso do nacionalismo para atender a todo tipo de interesses pessoais e/ou grupais. Os seguintes fragmentos são de quatro dos filmes analisados nesta pesquisa: Les dones migrades desafiem la invisibilitat, Flores de otro mundo, Quan la mare torna a casa per Nadal, Flores de otro mundo e Pan y Rosas. Um tema comum a todos eles é o trabalho migrado, mas especialmente em Flores de otro mundo também são expostas questões como as relações com os autóctones. Em La calle Hester (1974), são tratadas tanto as relações de gênero como a assimilação, enquanto em Relou (1999) o tema é o machismo e em Muso. Dones subsaharianes $i$ emigració, o movimento de mulheres em Senegal e as diferenças entre o papel da mulher naquele país e em Catalunha (e de como essa diferença resulta na dupla jornada laboral feminina em Catalunha). A multiculturalidade é abordada em Oriente es oriente (2000) no tocante à religião, enquanto em Mississipi Masala (1992) ela é discutida através das relações de um casal interracial. Finalmente, em El Jardín del Edén (1994), se discute a assimilação desde a perspectiva da "minoria étnica". A sequência escolhida deste último filme para o final de Trajectes invisibles... joga com a identificação da pessoa expectadora com uma expectadora diegética, subvertendo o que normalmente é usado no cinema como um efeito naturalizante. Nessa sequência, uma mulher assiste a uma entrevista na televisão, na qual uma indígena mexicana narra o impacto da cultura branca e o processo de 
A representação audiovisual das mulheres migradas

perda e aculturação pelo que passava sua aldeia. A expectadora começa a chorar e o expectador, emocionalmente identificado com a personagem, se comove.

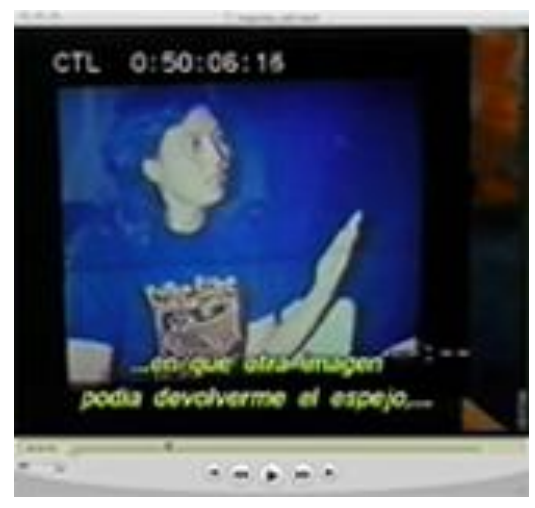

http://dl.dropbox.com/u/47943088/trajectes_tall.mp4

Já em Quan la mare torna a casa per Nadal, observa-se um olhar marcado por uma tentativa de intervenção mínima, como se se tratara de uma mosca na parede. Assim, observa-se um estilo de representação (quase) sem entrevistas, em que a câmara pode passar um longo tempo observando como a protagonista realiza as tarefas domésticas e cuida da filha de seus empregadores, como se não houvesse mais ninguém no recinto além delas. Embora normalmente se possa objetar que esse tipo de olhar se baseia numa falsa objetividade (como se uma gravação não interferisse com os fatos), esse filme nos permite tomar consciência do trabalho realizado pela protagonista: do que custa, do tempo e esforço que consume e de que normalmente tudo isso passa despercebido, por privado e invisível para a sociedade.

Apesar de que Quan la mare torna a casa per Nadal se aproxime à "modalidade de observação" (Nichols, 1991), uma visualização atenta é capaz de verificar que a diretora na verdade chega a intervir num momento chave, embora muito discretamente. De toda maneira, a concepção de "observação" 
que se tem dessa se distancia consideravelmente da que propõe o "estilo jornalístico" encontrado em Trata de Blancas.
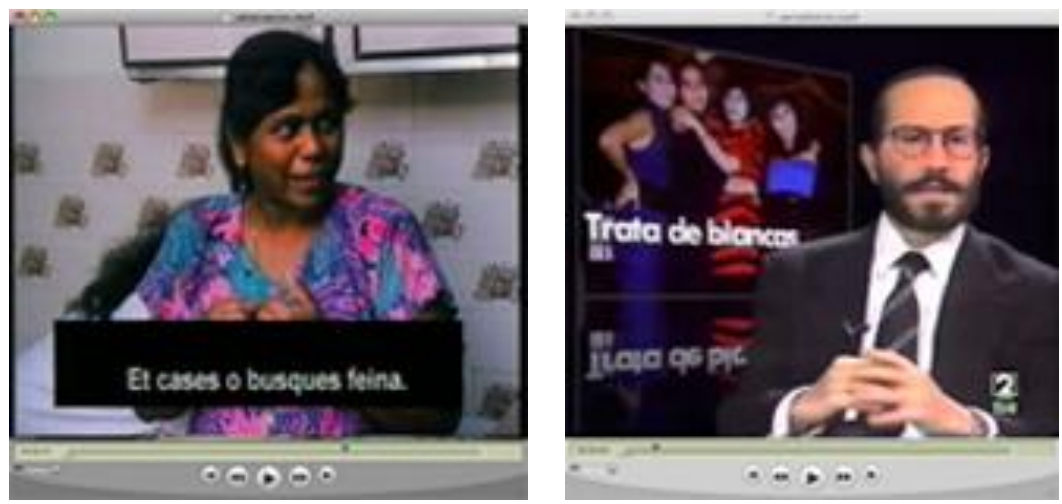

http://dl.dropbox.com/u/47943088/quan la mare_2.mp4 $e$

http://dl.dropbox.com/u/47943088/periodistico.mp4

Assim, em Trata de Blancas, ainda que o documentário propriamente dito seja um representante da "modalidade expositiva", na apresentação temos uma mostra do "estilo jornalístico", marcada por uma estética de noticiário e seu ar de credibilidade, objetividade e profissionalidade. Apesar da maior ambiguidade da segunda parte, o enunciado taxativo $e$ sensacionalista realizado na apresentação sob o "estilo jornalístico" da primeira parte dá uma pauta de leitura muito clara para a interpretação das possíveis entrelinhas da segunda. Assim, embora o audiovisual tenha o mérito de tentar abordar o tráfico de mulheres como um processo, sem embargo, sua apresentação ao "estilo jornalístico" é um tanto sensacionalista e vitimizante: dá a impressão de que, para que as migradas que se prostituem possam ser aceitáveis, têm que ter sido enganadas e o seu trabalho estar justificado como fruto do seu desespero pela pobreza de seus países. 
A representação audiovisual das mulheres migradas

\section{Conclusão}

Neste artigo busquei mostrar, através de exemplos concretos, como se articula a representação das mulheres migradas nos audiovisuais analisados. Apesar da variedade do material, foram constatadas determinadas recorrências na representação das mulheres migradas, assim como das estratégias de representação que articulam esses discursos.

Como sugerido, essas representações frequentemente veiculam estereótipos negativos, que parecem justificar $e$ reproduzir o lugar subalterno das mulheres migradas no contexto migratório. São alusões mais ou menos diretas a preconceitos de gênero, classe e "raça", que contêm uma mensagem discriminatória tanto mais potente, quanto mais banalizada. Igualmente, essas representações negativas também são com frequência acompanhadas por determinadas convenções estéticas e estilísticas, ainda que existam certas exceções. Como norma geral, os audiovisuais baseados em concepção da imagem como verdade e nas modalidades jornalísticas e de exposição são mais propensos a essas ocorrências.

Por outro lado, esta pesquisa deixa entrever que, apesar da existência de um discurso dominante centrado em representações negativas, também podem ser encontrados discursos como estratégias de representação que desafiam esses estereótipos. Ditas estratégias podem ter lugar tanto em estilos de representação assumidamente auto-reflexivos (como em $O$ totes o cap), quanto na criação de narrativas críticas que valorizam as mulheres migradas e questionam os interesses subjacentes a sua posição subordinada nos países receptores (Quan la mare torna a casa per Nadal).

\section{Referências bibliográficas}

ARGOTE, Rosabel. La mujer inmigrante en el cine español del inaugurado siglo XXI. Feminismo/s (2), Alicante, Editora da Universidade de Alicante, 2003, pp.121-138. 
BUTLER, Judith. Gender Trouble: Feminism and the subversion of identity. New York, Routledge, 1990.

Fondo DE POBlación de las NACIONES Unidas. (ed.) State of World Population 2006. A Passage to hope: women and international migration. New York, NFPA, 2006.

GREGoRIO, Carmen. Procesos migratorios y desigualdad de género. In: GarCíA-MinA, Ana e CARRASCO, Maria José. (eds.) Cuestiones de género en el fenómeno de las migraciones. Madrid, Universidad Pontificia Comillas, 2002, pp.11-38.

HARAWAY, Donna. Simians, cyborgs, and women - the reinvention of nature. New York, Routledge, 1991.

KING, Russel e WoOD, Nancy. (Eds.). Media and Migration: Constructions of mobility and difference. London, Routledge, 2001.

LARIO, Manuel et alii. Medios de comunicación e inmigración. Murcia, Caja de Ahorros del Mediterráneo, 2006.

LORITE, Nicolas. (dir.) Tratamiento informativo de la inmigración en España, 2002. Madrid, Ministerio de Trabajo y Asuntos Sociales, IMSERSO, 2004.

NiCHOLS, Bill. Representing Reality: Issues and Concepts in Documentary. Bloomington, Indiana University Press, 1991.

PARELlA, Sonia. Mujer, inmigrante y trabajadora: la triple discriminación. Rubí (Barcelona), Anthropos Editorial, 2003.

PÉREZ, Lola. Obstáculos y oportunidades para mejorar la cobertura de la inmigración en femenino en los medios. Mujeres en Red. El periódico feminista (32), 2008. Disponivel em: $<$ http://www.mujeresenred.net/spip.php?article1058> - acesso em: 05 de abril de 2008.

Rodrigo, Miguel e MedinA, Pilar. Posmodernidad y Crisis de Identidad. Revista Científica de Información y Comunicación (3), Sevilla, 2006, pp.126-146.

ROSENSTONE, Robert. El pasado en imágenes. El desafío del cine a nuestra idea de la historia. Barcelona, Editorial Arial, 1997. 
A representação audiovisual das mulheres migradas

SANTAOlalla, Isabel. Los "otros": etnicidad y "raza" en el cine español contemporáneo. Zaragoza, Prensas Universitarias de Zaragoza, 2005.

SIPI, Remei; ARAYA, Mariel. Les Dones Migrades: apunts, històries, reflexions, aportacions... Barcelona, Institut Català de les Dones, 2005.

STOLKE, Verena. Talking Culture: New Boundaries, New Rhetorics of Exclusion in Europe. Current Anthropology, Chicago, vol. 36, $\mathrm{n}^{\circ} 1$, 1995, pp.1-24.

WeINRICHTER, Antonio. Desuíos de lo real. El cine de no ficción. Madrid, T\&B editores, 2004.

\section{Filmografia analisada}

Cuando dejé mi terra. Direção: Lulú Martorell. Produção: Televisión Española. Madri: TVE, 1996. 1 videocassete (46 min., 10s.), VHS, son., color.

Dona, immigració i integració. Direção: Milagros Pérez Oliva. Produção: Barcelona TV. Barcelona: BTV, 1998. 1 videocassete (85 min.), VHS, son., color.

Domingo si Dios quiere. Direção: Yamina Benguigui. Produção: Bandits Longs e ARP. França: BL/ARP, 2001. 1 DVD (98 min.), DVD, son., color.

Extranjeras. Direção: Helena Taberna. Produção: Lamia Producciones Audiovisuales S.L. e Euskal Telebista S.A. Espanha: Lamia Producciones, 2003. 1 DVD (75 min), DVD, son., color.

Flores de outro mundo. Direção: Icíar Bollaín. Produção: Santiago García de Leániz. Espanha: La Iguana/Alta Films, 1999. 1 DVD (105 min), DVD, son., color.

Hogares, cuidados y fronteras. Produção: Cruz Roja Española, Universidad Complutense de Madrid, Bradford Youth Development, Verein Maiz e Universität Hamburg. Espanha, Inglaterra, Áustria, Alemanha: CRE/ UCM/ BYD/ VM/ UH, 2004. 1 DVD (8 min., 31 s.), DVD, son., color. 
La promesa. Direção: Luc y Jean-Paul Dardenne. Produção: Luc e JeanPaul Dardenne, Hassen Daidoul. Bélgica: Les Films du Fleuve/Touza Productions \& Touza Films, 1996. 1 videocassete (93 min.), VHS, son., color.

Las mujeres de verdad tienen curvas. Direção: Patricia Cardoso. Produção: George Lavoo e Effie T. Brown. EUA: Lavoo Productions, 2002. 1 DVD (90 min), DVD, son., color.

Les dones immigrades desafiem la invisibilitat. Direção: Dones d'Horta. Produção: Dones Creant Espais. Barcelona: Migramedia, 2000. 1 DVD (35 min), DVD, son., color.

Maria Llena Eres de Gracia. Direção: Joshua Marston. Produção: Paul Mezey. EUA: Journeyman Productions/Tucán Producciones/Altercine, 2004. 1 DVD (110 min), DVD, son., color.

Mujeres de hoy. Direção: Enrique Brasó. Produção: Maria Belén Díaz. Madrid: TVE/ IORT/ Instituto de la Mujer, 2004. 1 DVD (26 min), DVD, son., color.

MUSO. Dones Subsaharianes i emigració. Direção: Agustí Corominas. Produção: Fons Català de Cooperació al Desenvolupament, Ajuntament de Granollers e Consell Comarcal del Vallès Oriental. Barcelona: Diputació de Barcelona/Oficina Técnica del Pla d'Igualtat, 2001. 1 DVD (50 min), DVD, son., color.

Noies negres a la recerca d'una educació. Direção: Anne Diack. Produção: Anne Diack. Inglaterra: The Open University/BBC TV, 1988. 1 videocassete (24 min., 26 s.), VHS, son., color.

Pan y rosas. Direção: Ken Loach. Produção: Ulrich Felsberg e Rebecca O'Brien. Gran Bretanha, Alemanha, Espanha: Parallax Pictures, Roadmovies Filmproduktion \& Tornasol/Alta Films Production, 2000. 1 DVD (110 min), DVD, son., color.

Quan la mare torna a casa per Nadal. Direção: Nilita Vachani. Produção: Vangelis Kalambakas e Nilita Vachani. Índia, Grécia: FilmSixteen/ ZDF/ Greek Film Centre, 1995. 1 DVD (1h 49 min), DVD, son., color.

O Totes o Cap. Direção: Concha Pinós e Flavio Signore. Produção: Concha Pinós. Barcelona: Sibila/Filmtel, 2003. 1 videocassete (26 min. 26 s.), VHS, son., color. 
A representação audiovisual das mulheres migradas

Si no dejan. Direção: Ana Torres. Produção: Ana Torres. Barcelona: Sin Pasta Producciones, 2004. 1 DVD (72 min.), DVD, son., color.

Struggle. Direção: Ruth Mader. Produção: Ruth Mader. Áustria: Struggle Films/Amour Fou Filmproduktion, 2005. 1 DVD (75 min.), DVD, son., color.

Trata de blancas. Direção: Pedro Erquícia. Produção: Joaquín López. Madri: TVE, 1993. 1 videocassete (52 min. 35 s.), VHS, son., color.

Trajectes invisibles. Les dones en les migracions. Direção: AAVV. Produção: Drac Màgic. Barcelona: Drac Màgic, 2004. 1 videocassete (52 min.), VHS, son., color.

\section{Filmografia referida}

Blue in the face. Direção: W. Wang, P. Auster. Produção: Miramax International. EUA: Miramax International, 1995. 1 DVD (85 min.), DVD, son., color.

Código desconocido. Direção: Michael Haneke. Produção: Marin Karmitz e Alain Sarde. França, Alemanha, Romênia: Bavaria Films/Canal +/ Filmex, 2000. 1 DVD (128 min.), DVD, son., color.

El Jardín del Edén. Direção: María Novaro. Produção: Jorge Sánchez. México, Canadá, Francia: IMCINE/ SOGIC/ SCF, 1994. 1 DVD (104 min.), DVD, son., color.

Españolas em París. Direção: Roberto Bodegas. Produção: Agata Films. França, Espanha: Agata Films, 1971. 1 DVD (102 min.), DVD, son., color.

La calle Hester. Direção: Joan Micklin. Produção: Raphael D. Silver. EUA: Midwest Films, 1975. 1 DVD (90 min.), DVD, son., color.

Las afinidades eletivas. Direção: Nils Loof. Produção: Nils Loof Film. Alemanha: NLF, 2001. 1 DVD (7 min.), DVD, son., color.

Mississipi Masala. Direção: Mira Nair. Produção: Black River Productions. Reino Unido, EUA: BRP, 1991. 1 DVD (118 min.), DVD, son., color. 
Oriente es Oriente. Direção: Damien O'Donnel. Produção: Assassin Films. Reino Unido: Assassin Films, 1999. 1 DVD (96 min.), DVD, son., color.

Relou. Direção: Fanta Régina Nacro. Produção: Little Bear. França: DFCR, 2000. 1 DVD (6 min.), DVD, son., color.

Rocco y sus hermanos. Direção: Luchino Visconti. Produção: Goffredo Lombardo. Itália, França: Titanus/ Les Films Marceau, 1960. 1 DVD (170 min.), DVD, son., branco e negro.

Surcos. Direção: J. A. Nieves Conde. Produção: Atenea Films. Espanha: Atenea Films, 1951. 1 DVD (100 min.), DVD, son., branco e negro. 